\title{
"His Car Refused to Cry": An Analysis of L1 Interference Lexical Errors in Zambian Grade 12 Esllearners' Written Discourse
}

\author{
Lazarous Fred Sinkala $^{1^{*}}$, Gift Kaira ${ }^{2}$, John Simwinga ${ }^{3}$ \\ ${ }^{I}$ Mpelembe Secondary School, Kitwe, Zambia \\ ${ }^{2}$ Mulungushi University, Kabwe, Zambia \\ ${ }^{3}$ University of Zambia, Department of Literature and Languages, Lusaka, Zambia
}

*Corresponding Author: Lazarous Fred Sinkala, Mpelembe Secondary School, Kitwe, Zambia

\begin{abstract}
This study examined first language interference lexical errors in English as a Second Language (ESL) written discourse with particular focus on some Zambian Grade Twelve learners' written narrative English pieces of composition. The study sought to: identify lexical errors committed by Grade Twelve pupils in narrative pieces of composition; classify the identified errors into specific types; relate the identified errors to specific first language aspects and explain how the identified errors hamper discourse coherence. The study was guided by two approaches: Contrastive Analysis (CA) and Error Analysis (EA). CA was used to identify similarities and differences between respective Zambian language (L1) and English (L2) while EA was used to explain the errors. Data were collected through examination of the scripts produced by Grade Twelve learners under national examinations conditions. Data were analysed by sorting out specific local language interference errors which were then categorized according to type of lexical item involved (whether verb or noun or pronoun). Follow up interviews with 15 examiners were conducted to deepen understanding and interpretation of the results. The data revealed the existence of various categories of local language interference errors at lexical level thereby confirming the theoretical position that learners of L2 tend to transfer the meaning from their mother tongue to the target language. The implication of these findings is that the occurrence of L1 interference errors is widespread, thereby possibly contributing to poor scores in the English Language examination by the learners. The study recommends that schools should undertake remedial teaching focusing on local language interference errors in order to enhance discourse coherence in the pieces of composition written by senior secondary school pupils.
\end{abstract}

Keywords: Cry, ESL, Lexical Errors, Contrastive Analysis (CA), Error Analysis (EA), Grade 12 Learners, Zambian.

\section{INTRODUCTION}

\subsection{Definition of First Language Interference}

Language interference is defined by Corder (1981) as that which learners carry over to or generalize in their knowledge about their native languageas they learn a target language. The native language is also known as the mother tongue or the first language (L1) while the target language is also known as the second language (L2). In this paper first language (L1) is to be understood as the child's first acquired language. This is the language to which the child is naturally exposed from birth as he/she grows up. In the context of the present study first L1 is any of the local Zambian languages acquired and used primarily in the homes and immediate communities. In this regard, some of the first languages are also community languages. L2 is to be regarded as the language which is acquired after the first language(s) and mostly outside both the home and the immediate community environment. The education system remains the major agent of this language in Zambia. In the context of the present study, English is the second language. It is not the language of the home for the majority of Zambians, even though it is increasingly becoming so among the Zambian elite, but is acquired through the education system.

L1 interference occurs in instances where learners of a second language tend to transfer and apply certain aspects of their first language at phonological, lexical and sentence level in the second language resulting in errors in the usage of the second language. It is the case that L1 interference 
remains one of the most common errors experienced by L2 learners. As observed by Wilkins (1972: 199) "When learning a foreign language an individual already knows his mother tongue, and it is this which he attempts to transfer. The transfer may prove to be justified because the structure of the two languages is similar- in that case we get 'positive transfer'or'facilitation'- or it may prove unjustified because the structures of the two languages are different in that case we get 'negative transfer' - or interference". This explanation seems to suggest that transfer is acceptable where it fits in with the target language but unacceptable where it does not. Dechert (1983) observes that the further apart the two languages are structurally, the higher the instances of errors made in L2 which bear traces of L1 structures. In both cases the interference may result from a strategy on the part of the learner which assumes or predicts equivalence, both formally and functionally, of two items or rules sharing either function or form.

Duly, Burt and Krashen (1982) suggest two possible ways of looking at language interference: the Psychological and the Sociolinguistic perspectives of language. The psychological perspective is due to interference from old habits when new ones are being learnt. An example of an L1 interference error from the psychological perspective is 'can you hear the aroma of fresh fish?' which could be a direct translation from any of the Zambian languages into English. On the other hand, the sociolinguistic perspective relates to language interactions that occur when two language communities are in contact. During the contact, there is borrowing and code-switching. Borrowing is the incorporation of linguistic material from one language into another while code-switching is the use of two language systems for communication. This is evidenced by a sudden brief shift from one language to another. The study being reported in this article is based on the psychological perception since the article seeks to analyze some errors which were due to interference from the old habits internalised under L1.

\subsection{Theoretical Framework}

In the field of Applied Linguistics, there are two major theories applicable to error analysis. These are contrastive analysis and error analysis which are based on the concept of structuralism, a branch of linguistics that emphasizes the significance of the interrelations between the elements that constitute a linguistic system. Error Analysis (EA) is the main theoretical framework that guided this study in identifying the L1 interference errors made by Grade 12 pupils in their written pieces of discourse. Contrastive Analysis (CA) was used to explain the sources of the errors on the basis of similarities and differences between respective Zambian language (L1s) and English (L2). Error Analysis was applied to identify instances of deviation from the norm in the way the DMs were used where error was understood to mean "a noticeable deviation from the adult grammar of a native speaker, reflecting the interlanguage competence of the learner"(Brown, 1980:205). Such errors result from the learner's lack of knowledge of correct rules of the target language.

\subsubsection{Definition of Error}

Brown (1980:205) has defined a linguistic error as "a noticeable deviation from the adult grammar of a native speaker, reflecting the interlanguage competence of the learner." He cites an example "Does John can sing?" where a preceding ' $d o$ ' auxiliary verb has been used as an error. In Applied Linguistics, an error is considered as a deviation from accepted rules of a language made by a learner of a second language. Such errors result from the learner's lack of knowledge of correct rules of the target language. A significant distinction is generally made between errors and mistakes which are not treated the same from a linguistic viewpoint. Ellis (1997) draws a distinction between an error and a mistake by suggesting the application of the consistency test. In this regard, if a learner uses the incorrect form consistently or repeatedly then an error is being committed. However, if the learner tends to switch between the correct form and the incorrect one periodically then a mistake is being committed. From the consistency test we can conclude that errors are committed as a result of lack of knowledge and cannot be self-corrected by the learner whereas mistakes are slips which can be selfcorrected by the learner. Errors are likely to occur repeatedly without being recognized by the learner. Hence, only the teacher or researcher would locate them, the learner would not (Gas and Selinker, 1994). It is the case, therefore, that errors occur when the learner does not know the rule and needs to be taught or shown that wrong knowledge has been applied to a particular situation. It is in this light that the researcher chose to focus on the L1 interference lexical errors committed by the Grade Twelve pupils in their final examinations. 


\subsubsection{Sources of Errors}

Selinker (1974:120) has identified five different strategies adopted by learners in interlanguage building as potential sources of errors. One of the five strategies as acknowledged by Selinker, is a case of negative intralingual transfer. He states that negative transfer usually occurs when writers transfer items and structures that are not the same in both languages. He further says within the theory of CA the greater the differences between the two languages, the more negative transfer can be expected. The present study is premised on the understanding that there are major structural differences between local Zambian languages which constitute L1s and English language which constitutes L2.

The source of errors can be either interlingual or intralingual. Interlingual errors are attributed to L1 interference. They occur due to negative transfer from L1 to the target language. Intralingua errors are those due to the nature or structure of the target language. According to Richards (1976) they are items produced by the learner which reflect not the structures of the mother tongue, but generalizations based on partial exposure to the target language. It is the case that such errors are caused by inadequate knowledge of the target language and can take the form of overgeneralization, over-simplification and induced errors (Corder, 1971).The process in which incorrect linguistic features or errors become a permanent part in which a person uses language is called fossilization. According to Nakuma (1998) fossilization is a term used to denote what appears to be a state of permanent failure on the part of an L2 learner to acquire a given feature of the target language. On the other hand, interlanguage is regarded as the kind of language that has aspects that are borrowed, transferred and generalized from the mother tongue. It is the type of language produced by second language and foreign learners who are in the process of learning a language (Richards et al. 1992).

\subsubsection{Categorisation of Errors}

According to Thornbury (1999) errors can be classified into three different types taking into account lexicon, grammar and discourse. Lexical errors are defined as the errors that are committed at word level. They include, for example, choosing the wrong word for the meaning the students want to express (I made my homework instead of I did my home work). Grammar errors involve writing faulty structures which may include wrong verbal tenses, incorrect verbal forms and syntax problems, among others. On the other hand, discourse errors are those "which relate to the way sentences are organized and linked in order to make whole texts" Thornbury (1999:114). The study being reported focussed on lexical errors.

\subsubsection{Error Analysis and Contrastive Analysis}

Error Analysis and Contrastive Analysis are common parlance in second language teaching and learning investigation. Fauziatic (2014:9) explains that "they constitute evolutionary phrases in the attempt to understand and explain the nature of the target language learners' performance." $\mathrm{He}$ identifies these two as being among the theories whose goal is to facilitate deeper understanding of the process involved in L2 teaching and learning.

\section{$>$ Error Analysis (EA)}

Brown (1980:166) defines error analysis as "the process carried out to observe, analyze, and classify the deviations of the rules of the second language and then to reveal the systems operated by learners." This perspective is similar to that of Crystal (1987:112) who has pointed out that "error analysis is a technique for identifying, classifying and systematically interpreting the unacceptable forms produced by someone learning a foreign language, using any of the principles and procedures provided by linguists." In stressing the importance of EA, Corder (1967: 125) points out that "the study of errors is part of the investigation of the process of language learning. In this respect, it resembles methodologically the study of the acquisition of the linguistic development of a learner and may give us indications as to the learning process."Error analysis provides information on pupils' errors to teachers who in turn use it to correct the pupils' written work, hence improving the effectiveness of their teaching. Richards et al. (1996:127) state that "error analysis has been conducted to identify strategies which learners use in language learning to track the causes of learners errors, obtain information on common difficulties in language learning or on how to prepare teaching materials." Similarly, Michaelides (1990:30) states that "the systematic analysis of student's errors 
can be of great value to all those concerned, i.e., teachers, students and the researchers. For teachers, it can offer a clear and reliable picture of his students' knowledge of the target language." According to Corder (1974) there are two objectives or EA: theoretical and applied. The theoretical objective explains what and how a learner learns when he/she studies a second language. The applied objective serves to enable the learner learn more efficiently by exploiting the knowledge of his/her dialect for pedagogical purposes. However, the study being reported is guided by the theoretical part because the applied is beyond the scope of the present study.

\section{$>$ Contrastive Analysis (CA)}

Lado (1957:2) defines Contrastive Analysis (CA) as "the systematic study of a pair of languages with a view to identifying their structural differences and similarities." The main focus of CA is to compare structural aspects of the learners L! With those of the L2 being learnt. According to Sridhar (1980:93:94) "the rationale for conducting contrastive studies comes mainly from three sources: (1) practical experience of the foreign language teachers, (2) studies of language contact in bilingual situations and (3) theory of learning." CA is important in this regard because of the possibility of L1 interference in the earning of L2 hence the need to overcome the L1 interference in L2 writing (Hui, 2010). For example, from a grammatical perspective, a contrast can be made between the use of subject and object personal pronouns in English and the local Zambian languages. It is generally agreed by foreign and second language teachers that a substantial number of persistent errors made by their students emanate from students' L1. This practice tends to result in the production of deviant sentences in the areas where the structures of the L1 and the L2 differ the most.

\subsection{Status of English in Zambia}

In Zambia, English has remained the official language at national level since independence. It has also remained the official language of classroom instruction from Grade One to the highest level of education following official proclamation by the Ministry of Education in 1965. As a result of Government decisions, English is required to be used as the only medium of instruction in all forms of post primary education in Zambia, in parliament, for the administration of the country, for all national and international official communication and in the more important commercial and industrial sectors. Further, English is the only official language that is enshrined in the Zambian Constitution, and is perceived by many as a passport to upward socio-economic mobility (Sekeleti, 1983). There are also seven Zambian languages which enjoy official status at regional level. These are: Bemba, Kaonde, Lozi, Lunda, Luvale, Nyanja and Tonga. They are used for certain official purposes such as literacy campaigns, broadcasting and the dissemination of official information to a limited degree. As officially stipulated, Bemba is required to be used in the Luapula, Northern, Muchinga, Copperbelt and Central Province (Kabwe, Mkushi, Kapiri-Mposhi and Serenje); Nyanja in Lusaka and Eastern Provinces; Tonga in Southern Province and parts of the Central Province (Kabwe rural, Chisamba, Chibombo and Mumbwa); Lozi in the Western Province and parts of Livingstone rural; Kaonde chiefly in the Solwezi and Kasempa districts; Lunda mainly in the Mwinilunga, Chizela, and parts of Kabompo districts and Luvale principally in Zambezi and parts of Kabompo districts. In the school curriculum, the seven regional official Zambian languages are taught only as school subjects in prescribed regions of the country. It is the case, therefore, that in Zambia, English as second language (ESL) is taught as a compulsory subject in the school curriculum and is considered the determining subject for certification purposes at secondary education level. To this end, English is considered to be an essential or indispensable language that learners should master if their success in secondary and tertiary education is to be assured. Inevitably, such masterly is expected to include the use of appropriate lexical items to express propositions.

\subsection{Statement of the Problem}

The preface to the Senior Secondary English Syllabus states that the syllabus "provides a sound basis required for the effective teaching of English at the Senior Secondary Level for the development of teaching materials and for the preparation of the Zambian School Examination and General Certificate of Education 'O' Level English Examination. Whilst the general format of the syllabus is essentially "structural" the recommended methodological interpretation is 'functional' and 'communicative'. As a result, High School learners should develop a high level of confidence in English, and be able to use the language effectively in everyday life, in the world of work and in their further education" 
(Ministry of Education, Science, Vocational Training and Early Education, 2013:v). There are four basic competence skills namely listening, speaking, reading and writing. Of the four skills, writing is one of the most important language modes for school success and is the one that is examined at Grade Twelve school certificate level. According to Lerner (2000) these skill areas are interrelated in the sense that good listening skills promote speaking, good speaking skills enhance reading and good instruction in reading improves writing while good writing skills improve one's knowledge and skills in speaking and reading. It is the case that ability to use the English Language effectively includes the employment of appropriate English language lexical items. However, this has not been the case with regard to Grade Twelve learners of English in Zambia. Every year, Chief examiners of ' $\mathrm{O}$ ' level English composition point out a number of concerns regarding the quality of written pieces of composition produced by the Grade Twelve learners. Most notable of these are first language interference, limited vocabulary, inadequate rhetorical organisation and poor or inadequate use of discourse markers (Chief Examiners reports 2014, 2015, 2016)resulting in poor scores and prompting the Chief Examiner in one of the reports, to describe the "candidates' linguistic ability" as "not impressive" and their performance as "below expected standard." Of the five concerns raised by Chief Examiners as listed above, first language interference lexical errors appear to pose the greatest challenge impacting negatively on discourse coherence and comprehensibility in the written pieces of discourse produced by Grade Twelve pupils. While this challenge has been duly acknowledged there is lack of systematic identification, description and explanation of the specific types of first language interference lexical errors resulting in inability by teachers to implement effective remedial measures. In the Zambian secondary school context, there is limited understanding of the specific types of L1 lexical errors in the written pieces of composition produced by Grade Twelve learners.

\subsection{Research Questions}

The study seeks to provide answers to the following questions:

(i) What are some of the lexical errors committed by Grade Twelve pupils in narrative pieces of composition;

(ii) In what specific categories do the errors identified in (i) above fall?;

(iii) From what aspects of the first language do these errors emanate?;

(iv) How do the identified errors hamper discourse coherence or comprehensibility?

\section{LITERATURE REVIEW}

Various studies have been conducted on L1 interference under both English as Foreign Language (EFL) and English as Second Language (ESL) settings. It was not the intention of the present study to undertake an exhaustive review of all such studies but to sample only those which were considered to be of direct bearing on the present task.

\subsection{Studies in Countries where English is used as a Foreign Language (EFL)}

One of the studies reviewed was that of Abdallah (2011:3) entitled 'Lexical Errors Made by InService English Language Teachers in Jordan' who observes that "lexis is one of the major problems which confront EFL learners and due to their "anemic vocabulary, they are variable to communicate their ideas as clearly as they would like to." He observed that writing ability is hampered by EFL learners' limited vocabulary. He cited both Fareh (1984), and Mukattash (1986) as saying that some of the pronunciation errors made by EFL learners were teacher-based. The learners' pronunciation is to a large extent influenced by that of their teachers'. He further observes that lexical errors are more serious than grammatical errors and distort comprehensibility.

Abdallah's study aimed at identifying the types of lexical errors made by in-service English Language teachers in Jordan. The sample of the study consisted of 50 in-service English language teachers. The data were gathered from the final examination papers. The results showed two main categories of errors: interlingua and intralingua. He observes that Interlingua errors take the form of translation, assumed synonymity and wrong collocation motivated by LI interference, while intralingua errors were due to phonic and graphic resemblance as well as over generalization.

Abdallah's study is similar to the current study in that both studies gathered data from the final examination papers. However, whereas Abdallah's study emphasized on establishing errors 
committed by in-service teachers of English language, the present study sought to look at the errors committed by Zambian Grade Twelve learners of English due to L1 interference. It involved a description of some instances of L1 interference in narrative pieces of compositions produced by Grade Twelve pupils

Bennui (2008: 72) conducted a study entitled 'A Study of L1 Interference in the Writing of Thai EFL Students' on L1 interference in the writing of Thai EFL students and observed that "thinking in English when writing in English was very difficult for Thai students. Their Thai language structures and culture inevitably interfered with their written English." He further observed that the interference of the Thai linguistic elements in students' written English arose in three aspects: grammatical structures, vocabulary items and discourse'.

The main objective of Bennui's study was to analyse and describe L1 interference in the third year English-minor students' paragraph writing in the Basic Writing course at Thaksin University. There were 28 third year English-minor students whose papers were sampled. Three levels of L1 interference, namely words, sentences and discourse, were analysed from samples of the students' paragraph writing in the final examination paper. It was found that literal translation of Thai words into English mainly represented features of L1 lexical interference in students' written English. Bennui concluded that the three levels of L1 interference represented more of negative transfer than positive transfer in the students' written English. Bennui's study concentrated on Thai EFL students while the current one focuses on Zambian learning and using English as a second language.

Subramanian (2009) undertook a study in Malaysia 'Error Analysis of the Written English Essays of Secondary School Students in Malaysia' to examine errors in a corpus of 72 essays written by 72 participants. The objective of the study was to investigate the types of errors made by Form Four students in their written work. The study sought to address the question: What are the six most common errors that students make in their essays.

The participants were 37 male and 35 female Form Four Malay students who were studying at a secondary school in Malaysia. They came from a non-English speaking background and hardly communicated in English outside the school. The instrument used for this study was participants' written essays and the Markin software was utilized to analyze the errors in the essays. Markin is a Windows 95/98/ME/NT4/2000/XP program developed by Martin Holmes in 1996. It was used as a tool to allow teachers to mark written materials done by students electronically. It is a program for marking and annotating text documents using a Windows computer. All of the errors in the essays were identified and classified into various categories.

The results of the study revealed that the six most common errors committed by the participants were singular/plural form, verb tense, word choice, preposition, subject-verb agreement and word order. These aspects of writing in English posed the most difficult problems to participants. The study shed light on the manner in which students internalize the rules of the target language, which is English.

Subramanian's study is similar to the current study in the sense that both studies analysed written essays from which they identified and classified errors into various categories. However, the instruments used and the procedure for analysis of data and the findings are different. Whereas Subramanian analyzed the errors using a designed computer programme, the analysis in the current study was done manually by the researcher because he was not aware of the existence of the same program.

Hamjah (2012) in an article entitled 'Error Analysis in Mother Tongue (Bima Language) Interference in Writing Skill' reports results of a study conducted on Bima language interference on English writing skills among students at Muhammadiyah University of Surakarta. The objectives of the study were to describe the type of errors made by the students at the university by showing error dominance, and to show the pedagogical consequence in language teaching of writing skills. The method used was case study because the study involved the writer observing activities by students when they conducted the teaching-learning process. He observed students of Bima from the English department. The techniques of collecting data were observation, interview, record and transcription. The result of the study showed three categories of errors made by students of Bima. The three were identified as morphological, lexical and syntax levels. Morphological level consists of omission of the prefixes and 
suffixes. Lexical level contains verbs, articles, pronouns, adverbs, nouns and conjunctions. The syntactical level include the tenses and the 'to be' verb.

However, while Hamjar concentrated on how one language interferes in the writing skills in English, the study did not give the causes as well as the explanation of the specific instances of L1 interference lexical errors.

\subsection{Studies in Africa where English is a Second Language.}

Another study that was reviewed was that of Noemi Soares Silva 'The Impact of Mother Tongue on Teaching English as a Foreign Language at Beginner Level'. In the dissertation, Silva (2008) examined the influence that Creole has on Capeverdean students learning English as a foreign language. Some theories of language acquisition and language transfer, such as Contrastive Analysis were employed in trying to describe, analyse and explain the errors made by low level students in their written work in order to carry out the research, a questionnaire for teachers was designed. A pilot-testing with English teachers was done and based on the difficulties observed by the teachers, some modifications were made concerning some words and clarity of some questions. Silva found that lack of materials was one of the many problems that had negative impact on the learning of a foreign language. The situation got worse when students do not have sufficient opportunities for speaking, listening and writing the target language. Further some teachers used Portuguese or Creole as median of instruction in the classroom, thereby diminishing students' exposure to the target language. The native language dominates at home and in some cases in the classroom.

Out of these findings, it was concluded that Creole has a negative impact on the teaching and learning of English as a foreign language. In terms of learning the structures, the mother tongue, in this case, Creole exerts a negative influence because the students transfer what they know in their mother tongue into English language.

However, while Silva's study concentrated on how the mother tongue impacted negatively on the teaching and learning of English language as a foreign language, it did not give a descriptive analysis of specific instances of L1 interference through lexical errors. In addition, Silva used a questionnaire to elicit information while the present study used naturally occurring written discourse as some of data.

Moonga (2012) examined general errors committed by Grade Eleven pupils learning English as a second language in selected schools in Kabwe and Monze districts of Zambia. Written essay questions were administered to 120 pupils in six selected schools. Using Error Analysis, the errors were categorized according to types. Through the focus group discussions, a variety of possible sources of pupil errors were pointed out. The study revealed four main groupings of errors: grammatical, morphological/lexical, semantic and phonological. The study revealed that most of the errors were due to Interlingua rather than intralingua influence. Multilingualism affects the quality of written English in the schools.

Whereas Moonga examined the general errors committed by some selected Grade Eleven pupils from two districts, the current study is based on written scripts produced by Grade Twelve examination writers sampled from the whole country with specific focus on L1 interference errors. The results of this study can be generalized to all the local languages in the country as opposed to two languages; Bemba and Tonga represented by Kabwe and Monze districts respectively in Moonga's study.

Mukuka (2010) in the study entitled 'An Analysis of Syntactic Errors committed by Bemba-Speaking High School Pupils Learning French in Lusaka Province, Zambia' examined the errors that are committed by Bemba-Speaking learners of French in Zambia. The study aimed at testing the theoretical position that First Language (L1) and Second Language (L2) interfere with the learning of Third Language (L3). Survey questionnaires were administered and were followed by written tests. The study revealed four major categories namely: Agreement, Word Order, Coordination and Sentence Structure. The results suggested that both L1 and L2 interfere with the learning of L3 construction.

Mukuka's study is relevant to the current study in that the aim is in line with the aim of this study; to identify, classify and analyze error in students' written productions. However, Mukuka's focus was on 
the syntactic errors made by Bemba-Speaking pupils in the learning of French while the focus in the current study is on L1 interference lexical errors made by Grade Twelve pupils in their English Language examinations. The study concentrated on how First Language (L1) and Second Language (L2) interfere with the learning of Third Language (L3), it did not give a descriptive analysis of specific instances of L1 interference through lexical errors. In addition, Mukuka used a questionnaire to elicit information while the present study used naturally occurring written discourse as some of data.

\section{Methodology}

\subsection{Research Design}

As Kombo and Tromp (2006) state, research design is the conceptual structure within which the planned research is conducted. Research design shows the planned outline the researcher has opted to use to generate answers to the research problems identified. Arising from this definition, it is the case that a research design provides the basis for the selection of appropriate research methods to be used in investigating a given phenomenon. In the present study the researcher employed descriptive research design with text analysis as specific research approach based on the perspective of written discourse as rule-structured object or product of a completed activity (Hyland, 2016).

Triangulation was applied in both data collection and analysis. This approach involves use of two or more theories, methods, data sources, or investigators in the study of a given phenomenon. As Mukonde (2009:45) indicates, "using triangulation can capture a more complete, holistic and contextual portrayal and reveal varied dimensions of a given phenomenon." Of the many types of triangulation given above, this study employed data triangulation and methodological triangulation. For data collection triangulation which involves collecting data at different sites and from different participants, the researcher collected Grade Twelve ESL learners' written pieces of composition scripts from a cross section of learners who had written the examinations from different centers in the country. Data analysis triangulation involved analysis carried out by the researcher as well as verification by markers and examiners at the examination centre where the data were being generated from. Methodological triangulation involved the application of primarily qualitative methods with descriptive statistics, to show the frequencies with which the errors occurred in the Grade Twelve ESL learners' written pieces of composition. According to Polonsky and Waller (2011:149), "Qualitative research methods involve utilizing a diverse range of data, including the spoken and printed word, record sound and vision, and images, forms, and structures in various media.'In this study, the type of data is qualitative because it is in form of words even though in some cases, descriptive statistics in form of frequency tables were used to display the type and frequency of errors.

\subsection{Sample Collection}

The sample or corpus for the study was collected in December, 2015 at the Grade 12 marking centre for English paper 1 (composition) during the marking exercise. Collecting data from scripts provided under final examinations ensured uniformity of questions answered and conditions for all the selected scripts under which they were answered. The marking centre as research site was deemed suitable to give a balanced picture of the types and sources of errors that Grade 12 examination candidates make in terms of their written compositions.

\subsection{Sample Size}

A total of 150 naturally produced pieces of written discourse (scripts) produced by the Grade Twelve candidates who wrote their examination in 2015 were selected out of which the errors were identified. The Examinations Council of Zambia English Language paper 1 which was written in 2015 comprised of two sections. Candidates were to answer two questions, one from each section, in 1 hour 45 minutes. In section 1, candidates were asked to write on one out of six topics. They were to write pieces of composition of about 250 to 350 words. Section 2 consisted of one guided composition question. Candidates were expected to write an article for the school magazine using the information from the table of traffic accidents statistics. The length of the article was to be between 250 and 350 words. 


\subsection{Data Collection}

The researcher examined each of the selected scripts for the presence of L1 lexical and grammatical errors by reading each script several times in order to identify specific occurrences of the errors. The identified errors were further presented to Fifteen examiners who were interviewed, through employing open-ended interviews, to ellicit from them information and confirmation of the errors that pupils make as obtained from the scripts. The interviews were recorded. The examiners responses were relied upon and were validated by the Chief and the Deputy Chief Examiners. An examiner is a teacher who has been trained and certified by ECZ to mark the examinations scripts. The training is conducted by the Chief Trainer, who in most cases is the Chief Examiner, and the Deputy. It is intensively conducted in seven days at a designated venue. At the end of the training session, those who pass are certified as examiners and are henceforth invited to mark the Grade 12 and GCE examination scripts. Both the chief examiner and the examiners identified instances as examples of lexical errors.

The researcher analysed naturally produced pieces of written discourse (scripts) by the Grade 12 candidates who had written under final examinations conditions which are set by the Examinations Council of Zambia (ECZ) and invigilated by teachers.

\subsection{Data Collection Instruments}

It is the case that data collection was conducted as follows: The researcher read each script several times to collect information about L1 lexical errors. Based on errors collected, the researcher interviewed 15 examiners at the marking centre including the Chief Examiner to verify the identified cases as errors of L1 interference. The interviews responses were recorded and transcribed. The research employed the interview guide as research instrument to verify the status of the identified lexical errors. According to Punch (2009:147), "the interview is the most prominent data collection tool in qualitative research. It is a very good way of accessing people's perceptions, meanings, definitions of situations and constructions of reality. It is also one of the most powerful ways of understanding others." Since the study was qualitative, no questionnaires were devised for this task.

\subsection{Data Analysis And Procedure}

\subsubsection{Analysis}

Data analysis was conducted in such a way as to answer the research questions and meet the set objectives. The study used document analysis as technique. Document analysis involves the process of collecting various documents and examining them in terms of content, discourse process, linguistic peculiarity or styles. The identified errors were categorised as either lexical in nature. They were further subdivided into wrong word, concord, wrong expressions, tense, and spelling. The errors were analyzed qualitatively under these categories and in relation to the objectives of the study.

\subsubsection{Procedure}

The study involved the description of some of the specific instances of first language interference lexical and grammatical errors in narrative pieces of composition produced by Grade Twelve pupils as they existed at the time of data collection. Various errors were taken note of, after which Error Analysis (EA) as well as Contrastive Analysis (CA) was applied to analyse them. The researcher discussed the data under the guidance of the CA and EA theories.

\section{Presentation of Findings}

The presentation is done in line with the subheadings which were derived from the objectives of the research.

\subsection{Identification of errors}

The first objective required the researcher to indentify the lexical errors that the Grade Twelve (G12) pupils make in their written narrative pieces of composition. In line with the first objective, it was discovered that a variety of L1 errors were committed by the G12 candidates in their final examinations due to various reasons. The lexical category was made up of words that are used wrongly in the target language. For example, most of the pupils use the words 'walk' or 'run' as 'move' in relation to mobility. This is an error influenced by L1 because in the local languages, the 
concept of motion is expressed using only one lexical item, while in English, the concept is expressed using different words depending on what is moving or the type of entity that is moving. This finding renders support to Moonga (2012) who observes that, in line with Corder (1974), a single word may show more than one error and appears, therefore, in more than one category or list.

Most of the lexical errors identified involved use of wrong words or wrong expressions. In English, concepts are expressed differently using different words such as state verbs of the senses and verbs of belonging. This is not the case with local languages in which the same word is used to refer to different concepts. When such words are used in English, they are considered as wrong words because they hamper discourse coherence or comprehensibility.

From the scripts which were analysed, some of the lexical errors observed are presented below.

\subsection{Classification of Errors}

\subsubsection{Verbs of the Senses}

In English, state verbs of the senses describe 'states' over which we have no control. For example, we hear with our ears, we see with our eyes, we smell with our noses, and we taste with our mouths.

\section{$>$ The Verb 'hear'}

It was observed from the errors that the word 'heard' in local languages refers to hearing, smelling, feeling, and tasting hence:

1. 'I heard something smelling' instead of 'I smelt something'

(Naliumfwa fimo filenunka - Bemba)

(Naumvwine kintu kya nunkilenga - Kaonde)

(Naliumwfine ikintui kyali kununka - Lamba)

(Namvela vinthu vinunka - Ngoni)

(Ndakamvwa cintu cinunka-Tonga)

(Napulika chintu kununkha-Tumbuka)

In 1 above, thestativeverb 'hear' was used to represent the concept of sense of smell instead of the appropriate verb 'smelt'. This is similar to $\mathbf{2}$ and $\mathbf{3 b e l o w}$ where the verb 'heard' was misapplied to refer to the sense of feeling and taste respectively.

2. 'I heard the kidneys paining' instead of 'I felt the kidneys paining'.

(Ni ngumfwainfyoshilekalipa - Bemba)

(Naumvwinenfyoyakolelenga - Kaonde)

(Naliumwineinfyoshalikusomena - Lamba)

(Ninvelamumenecikalipile - Ngoni)

(Ndakamvwansazilacisa-Tonga)

(Napulikazisokubaba-Tumbuka)

3. 'The food was heard nicely' instead of 'the food tasted nice'.

(Ifyakulyanafyunfwikabwino - Bemba)

(Baikujabiaumvwanikilebulongo - Kaonde)

(Naliumfwineifyakulyaukuwama - Lamba)

(Vakudyavimvekabwino - Ngoni)

(Cakulyacakalikulimvisyakabotu-Tonga)

(Chakulyacapulikikamakola-Tumbuka) 


\section{The Verb 'eat'}

The verb ' $\boldsymbol{e a t}$ ' in English refers to the act of putting food in the mouth, chewing it and swallowing. Unlike in English the word 'eat' in local languages is not only applied to the sense of taste but also to squandering and to scoring points or high marks in academic subjects such as mathematics. In $\mathbf{4}$ and $\mathbf{5}$ below the errors were due to misapplication of the verb 'eat';

4. He ate the church money instead of 'he squandered the church money'

(Alilyaindalamashachalici)

(Wajilemali a kibwilo - Kaonde)

(Alilileindalamashakipwilo - Lamba)

(Anady and alamasha chichi - Ngoni)

(Wakaalyamaliakucikombelo - Tonga)

5. I ate all the Mathematics questions. (Nalilyainsamushishonse)

(Najilensamushiyonse - Kaonde)

(Nalilileinsamushishonse - Lamba)

(Ninadyasamuzonse - Ngoni)

(Ndakazijanansamuzizyoonse - Tonga)

(Nangulyaghosemafumbo mu masamu - Tumbuka)

\subsubsection{Concept of Motion}

'Run', 'climb', and 'jump' are verbs that denote motion in English. However, in response to question

2 'Give an account of an occasion when you felt it was too late to do anything', the candidates' scripts revealed that these verbs were wrongly used to express the concept of motion, thereby committing the following lexical errors;

\section{$>$ The Verb 'to run'}

The bus was running very fast. Here, the verb 'run' was misused to mean 'move'. This was so because the word 'run' in local languages refers to mobility regardless of what is moving or the entity that is moving.

(Run) Ukubutuka (Bemba/Lamba)

Kunyema (Kaonde)

6. 'The bus was running very fast' instead of 'The bus was moving very fast'

(Basiyacilabutukasana -Bemba)

(Sakyawanyemenengakyakinekine - Kaonde)

(Sakyaalibutukaukwachi - Lamba)

(Basiyezeyathamangangako - Ngoni)

(Bbaasiyakalikulundukakapati-Tonga)

(Yaendanga-Tumbuka (I was moving/walking)

7. 'The snake was running in the grass' instead of 'the snake was moving in the grass'.

(Insokayacilabutukamufyani - Bemba)

(Mulolomanymenengamunsono - Kaonde)

(Insokayalikubutukamufyani - Lamba)

(Njokayenzeutukamumauzu - Ngoni)

(Inzokayakalikulundukamubwizu-Tonga) 
(Njokayacimbilanga-Tumbuka)

8. 'The heart is running fast' instead of 'The heart is beating fast'.

(moyoulalunduka-Tonga)

(Mutimauthamangangako - Ngoni)

(Mtimawacimbilanga-Tumbuka)

9. 'Time is running 'instead of 'Time is moving'.

(Ciindicilalunduka - Tonga

(Inshitailebutuka - Bemba

(Impindiikusamala -Namwanga)

(Impindiyalikubutuka - Lamba)

(Kimyekibenakunyema - Kaonde)

(Nthawiithamangakwambiri - Ngoni)

(Nyengoyikwenda-Tumbuka)

\section{The Verb 'to climb'}

Whereas the verb 'climb' in English means going up something, in local languages, it refers to going up as well as raising to higher levels, hence;

(Climb) Ukunina (Bemba)

10. 'She climbed the car' instead of 'She got on the car'

(Alininamotoka- Bemba)

(Wakanjijilemotoka - Kaonde)

(Alininshilemotoka - Lamba)

(Anakwelagalimoto - Ngoni)

(Wakwelamootokala - Tonga)

(Waka kwela galimoto - Tumbuka)

11. 'The doctor said the temperature is climbing 'instead of 'the doctor said the temperature is rising'.

(Badokotabatiletempulicailenina. - Bemba)

(Ba dokotabaambiambakukabakwamubijiubenakukanjila - Kaonde)

(Ba dokotabali labile atiukukabakwamubilikuliKunisa)

(Dotoloanatitempecayakwela -Ngoni)

(Dokotawakaambakutitempulicayakwela-Tonga)

(A dokotabakati - Tumbuka)

12. 'He climbed the plane' instead of 'He boarded the plane'

(Alininaindeke - Bemba)

(Nkanjijilendeke - Kaonde)

(Nalinishuleindeke - Lamba)

(Anakwelandeko - Ngoni)

(Wakatantandeke - Tonga)

(Wakakwelandeke - Tumbuka)

\section{$>$ The Verb 'to jump'}

In English, the verb 'jump' refers to a quick movement off the ground or away from the surface. This is not the case in local languages where this word also refers to crossing hence; 
13. She jumped the Road

(Alitolokaumusebo - Bemba)

(Watumbukilemukwakwa - Kaonde)

(Ali kilulikeumusebo - Lamba)

(Anajumpamujeo - Ngoni)

(Wakasotokamugwagwa - Tonga)

(Wakajumpamuseu - Tumbuka)

The lexical items above are a source of errors in L2 because of the transfer of meaning. In each case, there was transfer of meaning and reference of the word from the mother tongue to English (L2). While in local languages, the meaning of a word allows that word to be used in different contexts, it is not the case with English.

\subsubsection{Wrong Word Usage}

Some of these errors are apparently committed because when writing, learners think and plan their compositions in local languages. Some words are literally translated from the respective Zambian local languages (L1) directly to English (L2). In answering questions 1(a) and (b), the following errors were observed:

\section{(Thorn) Umunga (Bemba/Namwanga/Mambwe)}

In English, a sharp and pricking object is expressed differently depending on the type of object. However, in Zambian local languages, it is expressed using one word regardless of the object. For instance;

'The thorn of the fish pricked my tongue' instead of 'The sharp bone of the fish pricked my tongue'. Whereas a thorn in English refers to a small sharp pointed part on the stem of some plants, in Zambian local languages the word refers to anything that is sharp and pricking hence:

14. The thorn of the fish pricked my tongue.

(umunga we sabiwalindasapalulimi - Bemba)

(Mwibawafisabiwangashilepalujimi - Kaonde)

(Umungawesabiwalindashilepalulimi - Lamba)

(Mungawansombawanilasapalulimi - Ngoni)

(Bumvwabwanswibwakandiyasaamulaka-Tonga)

15. 'The snake had a lot of thorns' instead of 'the snake had a lot of bones'.

(insokayalikweteimyungaishingi)

(Mulolomujinamibayavula - Kaonde)

(Insokailinemyungaishingi - Lamba)

(Njokainalindimyungayambiri - Ngoni)

(Inzokayakali a mamwvamanji - Tonga)

\section{The word 'cry'}

The concept of sound is expressed differently in English using different words for different objects. For example, the word 'cry' in English refers to producing tears from one's eyes because one is unhappy or hurt. However, in Zambian local languages the word refers to making any sound hence; (Crying) Ukulila (Bemba/Lamba)

16. 'The phone is crying' instead of 'The phone is ringing'. The phone is crying.

(Foniilelila - Bemba)

(Foniubenakujilakujila - Kaonde) 
(Foniikulila - Lamba)

(Foniilila - Ngoni)

(Fooniilalile-Tonga)

(Foniyikulila - Tumbuka)

17. 'The church gong $\underline{\text { cries }}$ every Sunday' instead of 'The church gong sounds every Sunday'.

(inyengeleyakuchaliciilalilacilamulungu - Bemba)

(ngengelayakipwitoijilajonse pa sande - Kaonde)

(Ingeleyakipwiloilalilalyonse pa sande - Lamba)

(Cingelele (belu) ililapamulunguulionse - Ngoni)

(Mulanguwakucikombeloulalilansondoansondo - Tonga)

(Beluyachalichiyikulilasabatayose - Tumbuka)

18. 'The cats cried a lot at night' instead of 'the cats mewed a lot at night'.

(Ba pushibacililasanaubushuku - Bemba)

(Bapushibajikilakyakinekinebutuku - Kaonde)

(Ba pushibakililaukwakuchiubushiku - Lamba)

(Ba pusibenzelingakousiku - Ngoni)

(Bakaazebakalilakapatimasiku - Tonga)

(Baconabangulilacomeneusiku - Tumbuka)

19. 'The car engine is crying' instead of 'The car engine is running'

(injiniyamotokailelila - Bemba)

(injiniwamotokaubenakujila - Kaonde)

(injiniyamotokailikulila - Lamba)

(injiniyamotokailila - Ngoni)

(Injiniyamootokalailalila - Tonga)

(Injiniyagalimotoyikulia - Tumbuka)

In Zambian local languages, the words 'thorn' and 'cry' refer to different objects. 'Thorn' in English refers to a small sharp pointed part on the stem of some plants, while in Zambian local languages it refers to anything sharp and pricking. 'Cry' in English refers to producing tears from one's eyes as opposed to the way it is used in Zambian local languages where the word refers to making any sound.

$>$ The pronoun 'they'

The pronoun 'they' in English denotes plural, that is, referring to more than one person or thing. This is not the case in Zambian local languages where the word 'they' $(\mathrm{Ba})$ also denotes respect in addition to plural. Due to this, candidates who attempted question 3 'Describe an occasion when you disagreed with someone very close to you by clearly stating what caused the disagreement and how you resolved it', ended up writing the following sentences;

20. 'They sent me to town' instead of 'He sent me to town'

21. 'They are calling you' instead of 'He is calling you' and

22. 'My uncle, they entered' instead of 'My uncle, he entered'

Bayamabaliyingila (Bemba)

Ba mwinshobatwelele (Kaonde)

Bamwinshobalingile (Lamba) 
Bamalumebeloba (Ngoni)

Ba acisyabakanjila (Tonga)

A Sibwenibanguijila (Tumbuka)

The error in (20), (21), and (22) is due to lack of concordance between the subject pronoun and its referent. Much as there is subject - verb agreement, there is no concordance in terms of number between the pronoun 'they' (subject) and its referent 'he' or 'uncle'. In English, the concept of plural always denotes number. Plural here refers to the form of a noun or a verb which refers to more than one person or thing. In Zambian local languages, it culturally, denotes respect for elders as well as number. Writing under examination conditions, the Grade Twelve pupils are under so much pressure that they unconsciously use systematic resources from their mother tongue in order to achieve meaning. This results in errors such as the one in (20), (21), and (22) above.

$>$ The word 'fall'

In English, the word 'fall' means dropping down from a higher level to a lower level. In local languages, the word refers to both falling and failing hence;

23. 'He fell the examination' instead of 'He failed the examination'

Aliponaamashindano (Bemba)

Waponeneekizamuneshoni (Kaonde)

Aliponeneekizamineshoni (Lamba)

Anaponamayeso (Ngoni)

Wakaufweelamusonko (Tonga)

Wakafelukavilingwa (Tumbuka)

$>$ The words 'clever' and 'intelligent'

In English, the words 'clever' and 'intelligent' do not mean the same. The word 'Clever' usually refers to being cunning, that is to get what someone wants by using tricks or cheating, whereas 'intelligent' refers to being good at learning and understanding things in a logical way. The words are not interchangeable. However, in Zambian local languages, the same word 'clever' is used to refer to either being intelligent or being clever hence

24. 'He is very clever' instead of 'He is very intelligent' when referring to a fast learner.

Alicenjelasana (Bemba)

Wajimukakyakinekine (Kaonde)

Alikengeleukwachi (Lamba)

Niwochenjelengak (Ngoni)

Ulicenjedekapati (Tonga)

Ngwazelu (Tumbuka)

The words 'borrow' and 'lend'

As in item above, in Zambian local languages, there is only one word to mean either borrow or lend hence;

25. 'He borrowed me some money' instead of 'he lent me some money'.

Alingashimakoindalama (Bemba)

Wankongweseshekomali (Kaonde)

Alinkongwehekaindalama (Lamba)

Ananibwelekandalama (Ngoni) 
Wakandikweletesyamali (Tonga)

Wakanibwelekandalama (Tumbuka)

The lexical items above are a source of errors in L2 because of the transfer of meaning. Learners transfer the meaning and reference of the word in their mother tongue to English (L2). They make direct translations from their mother tongue. This is what Selinker (1972) refers to when talking about language transfer. Most of the errors above are due to the fact that one word in most local languages in Zambia can have multiple meanings and referents. For example in (1) above, the context in which the word 'hearing' is used, determines the meaning. Similarly, the meaning in the other cases above is highly contextualized.

As observed in the items above, depending on the situation or context, a word in Zambian local languages can refer to more than one entity. This is manifested in the pupils' written narrative pieces of composition at G12 and is treated as a wrong word used. This is because when writing the compositions during examinations, there is a tendency by the pupils to over generalize the use of these lexical items.

\section{DiscuSSiON OF Findings, CONCLUSION AND RECOMMENDATIONS}

\subsection{Discussion}

\subsubsection{Identification of Errors}

With regard to lexical errors, when expressing concepts, pupils use wrong words. This is because unlike English, in many cases Zambian local languages use one and the same word to refer to different concepts. When such words are used in English, they hamper discourse coherence or comprehensibility which looks odd to native speakers of English. This requires that Grade Twelve pupils make a distinction in their choice of words to use in their written pieces of discourse.

This explains why the use of words in items (1) to (25) in the previous chapter is unacceptable in English but acceptable and are correctly used when translated to Zambian local languages. For example, in the case of item (14) in the previous chapter, while an object that is sharp and pricking is expressed differently in English, in local languages, it is expressed using one word regardless of the object hence sentences such as 'the thorn of the fish' and 'The snake had a lot of thorns'.

\subsubsection{Relation of the Errors to Specific Aspects of L1}

\section{- Interlingua Transfer}

From the scripts that were analysed, some of the Interlingua errors took the form of vocabulary items such as proverbs. For example the Bemba proverb, “ubuchendebwamwaumetabutobaing'anda" (Bemba) (the promiscuity of a man does not break a marriage), was transcribed as "the prostitute of a man does not break the house."In its cultural setting, this proverb means that when a married man is promiscuous or adulterous, his marriage would not necessarily break up. The wife would be advised by everyone not to divorce the promiscuous husband because that is 'how and what men are and are meant to be'. Otherwise, when it is a wife who is involved in promiscuity or adulterous behavior, that would warrant instant divorce. When directly translated into English, 'the prostitute of a man does not break the house', this sentence becomes awkward. A sentence of this nature is not acceptable in English because it is meaningless. In such cases, the learner lacks linguistic performance capacity which requires internalization of social cultural aspects of language use. This is because the use of proverbs is social cultural specific and therefore, a proverb as used in one language cannot be transferred to another language. The meaning cannot be conveyed by word for word translation. Proverbs are sensitive to social cultural factors or contexts. That is why in English, someone can say 'He kicked the bucket' (He died). When translated word for word into any of Zambian local languages, the meaning would be completely distorted.

These findings are in agreement with the EA theoretical position that interlanguage is regarded as the kind of language that has aspects that are borrowed, transferred and generalised from the mother tongue.

The implication is that the learners have not sufficiently mastered these issues which means that teachers would have to focus on teaching vocabulary acquisition, sentence structure as well as social cultural aspects of the target language. 
These findings confirm the theoretical position that learners of L2 tend to transfer the meaning from their mother tongue to the target language. These findings seem to suggest that when writing their English Language examinations, Grade Twelve pupils commit some errors which are attributed to L1 transfer. Similarly, these findings are in line with the theoretical position on Contrastive Analysis. Based on behaviorist and structural theories, the basic assumption for Contrastive Analysis Hypothesis $(\mathrm{CAH})$ was that "the principle barrier to second language acquisition is the interference of the first language with the second language system..." and "...that second language learning basically involved the overcoming of the differences between the two linguistic systems - the native and the target language" Brown, (1980: 148). According to Richards (1971), they are items produced by the learner which reflect not the structure of the mother tongue, but generalizations based on partial exposure to the target language. The learner, in this case, tries to "derive the rules behind the data to which he/she has been exposed, and may develop hypotheses that correspond neither to the mother tongue nor to the target language" Richards, (1974:6). In other words, they produce deviant or incorrect sentences by erroneously applying their knowledge of L1 rules and structures to L2 situations.

As has been noted in studies such as those by Bennui (2008), Kittiporn (2013) and Silva (1993)and confirmed by the findings of this study, different structures between two languages cause the errors as the result of language interference. The differences between the English grammar and our local languages grammar would not create problems if the learners' understanding of English grammar is good. If the learners have a good understanding of the grammatical rules of English, they will not be influenced by their local languages grammar when they are writing their English narrative pieces of composition. However if their understanding of English grammar is not good, they will be influenced much by the grammar of their local languages.

Therefore, negative influence of L1 on L2 should not be underestimated. Swann (1992) emphasizes that younger children need experience of a wide range of reading and writing activities in order to perform well at a later stage in their school career. Here, the researcher is not against the use of L1 as a tool for L2 acquisition, but is also of the idea that learners need exposure of the L2 at an early stage to be able to learn it effectively. Otherwise, the learners will continue transferring the meaning from their mother tongue to English which evidently results into making similar errors in their written English pieces of narrative composition during their examinations.

The identified errors also seem to suggest that there is a serious lack of exposure to English especially with the schools from rural areas. It seems learners in rural areas are mostly exposed to their first language around the schools and communities. Learners are only forced to speak English in an event that their teacher cannot speak their first language or if there is a deliberate rule at school that compels everyone to speak English. Unfortunately, even with such a law, this only takes place during school hours.

The findings also confirm those from previous studies by other scholars such as Abdallah (2011), Bennui, (2008) and Moonga (2012). The aim of Abdallah's study was to identify the types of lexical errors made by in-service English Language teachers in Jordan. The results showed two main categories of errors; Interlingua and intralingua errors. It was concluded that Interlingua errors take the form of translation, assumed synonyinity, and wrong collocation which is motivated by LI. Intralingua errors were due to phonic and graphic resemblance and over generalization.

Further, the findings confirm those of Bennui's (2008). He observed that thinking in English when writing in English is very difficult for Thai students. Their Thai language structures and culture inevitably interfere with their written English. He further observed that the interference of the Thai linguistic elements in students' written English arises in three aspects: grammatical structures, vocabulary items and discourse'. The conclusion was that the three levels of L1 interference represent more negative transfer than positive transfer in the students' written English.

\subsubsection{How the Errors Hamper Discourse Comprehensibility}

From the scripts, direct translation was noted when pupils use proverbs in their written pieces of composition. They translate the proverb from their mother tongue, word for word thereby distorting both the lexical comprehensibility. 
L1 Lexical errors are mainly due to the limited English vocabulary the Grade Twelve learners possess, especially with lexical verbs and nouns. This is because, unlike English, one lexical verb in Zambian local languages can be used in different contexts. In English, different contexts use different words. Most of the errors under the lexical category involved either use of Wrong Words or use of Wrong Expressions. The category was dominated by words that are used wrongly in the target language. For example, in item (3) above, most pupils use the word 'walk' or 'run' to mean 'move' in relation to vehicles, which becomes an error influenced by L1 because in the Zambian local languages, the words 'walk' and 'run' refer to mobility. In English, vehicles do not walk or runinstead they accelerate, drive, or simply speed up or pick up speed. This shows that learners have not mastered the vocabulary of mobility. When the word 'walk' or 'run' is used in English to refer to mobility, one would wonder how a vehicle which is not human can actually walk or run. The implication is that such a learner has not understood the use of verbs of motion in English. Such a learner needs remedial teaching of vocabulary.

Some other examples encountered are:

I heard something smelling. In the local languages, the equivalence for the word 'hear' is 'umfwa'. While 'umfwa' in these languages, depending on context, could refer to either hearing, smelling, feeling or tasting it is not the case in English. In this case, the sentence 'I heard something smelling' is a direct translation of Naliumfwafimofilenunka. In English, it is only the ears that can hear. The nose does not hear but smells.

Similarly, 'I hear the kidneys paining' is direct translation of Ni ngumfwainfyoshilekalipa- Bemba. 'The bus was running very fast' is direct translation of Basiyacilabutukasana-Bemba. 'He ate the church money' instead of 'he squandered the church money' is direct translation of Alilyaindalamashachalici (Bemba). The denotative word for eat in local languages in Zambia is 'kudya'. However, this word is also commonly used in local languages as a euphemism to mean squandering, theft, or fraud, which is not the case in English. While it would be acceptable in the local languages to say 'he ate the church money' (Alilyaindalamashachalici) (Bemba), it would not be acceptable in English, because it would hamper discourse comprehensibility.

Where as in English, concepts as well as situations are expressed differently using a variety of vocabulary and sentence structures, in Zambian local languages one word is used to refer to different concepts. When such words are used in English, they are considered as wrong words because they hamper discourse coherence or comprehensibility as is the case in the example above. Where in English, a distinction is made between house and home, local languages use one word "ing' anda" (Bemba).

For instance, in responding to question 2 and 3 of the 2015 School Certificate English Language examination, the Grade Twelve pupils committed the following lexical errors as revealed through some written scripts that were examined and as stated in chapter 4 of this study;

i. 'send me climbing money' instead of 'fare'

ii. 'I will climb Power Tools Bus because it walks very quickly' instead of 'board' and 'moves'

iii. "the bus died on the road and it slept there for three days" instead of 'broke down' and 'remained'

iv. 'The bus cried after three days' instead of 'started'

v. 'Mathematics was very strong but History was soft and I ate 93\%. I broke only $7 \%$ instead of 'hard' or 'difficult', 'easy', 'scored' and 'failed by'.

vi. 'Please sit well and greet my mother' instead of 'stay' well.

The lexical items above are a source of errors in L2 because of the transfer of meaning. Learners transfer the meaning and reference of the word in their mother tongue to English (L2). In English, money paid in order for a person to be transported from one place to the other is called a fare, which is a noun. In local languages, this is not the case because such nouns are dependent on the intended use, situation, or action that is being performed. For instance, in local languages, an action such as climbing (ukunina - Bemba) would suffice for 'boarding'. Where in English, words such as 
'boarding' in the case of buses are used, local languages use action words such as climbing, thereby naming the bus fare 'climbing money'.

Similarly, in Zambian local languages verbs such as walk, sleep, cry and die are used with reference to animate entities such as people, animals and birds with which people interacted before the advent of machines like vehicles, trains and bicycles. When these machines came their way, the state verbs were applied due to the equivalent modes of transport such as donkeys, horses and oxen which they were using. Because animals walk, sleep, cry and die, these verbs are as well applied to machines, hence the $\mathrm{L} 1$ interference in the lexical items above.

'Strong', 'soft' and 'ate' are direct lexical translations from local languages which make cross cutting errors which hamper discourse coherence and comprehensibility because there are no alternatives for 'strong' (ukukosa - Bemba) as is the case in English which uses synonyms such as 'difficult', 'hard' and 'tough'. This goes with other lexical items mentioned in this context. The word 'broke' (ukutoba - Bemba) has no substitute in English, hence the only way out is direct translation of the lexical item into English, a subconscious act that leads to the writers committing the error. Moreover, in English, the term can be a phrasal verb - 'got wrong'. Another L1 interference lexical error is 'sit well'. The word that came first to the writer's mind was the verb 'sit' whose equivalent is 'ukwikala - Bemba', hence 'sit well' (mwikalebwino - Bemba) instead of stay well.

Interlingua transfer, which is the transfer from the mother tongue, is a major strategy that learners of a language use when they are short of the required linguistic resources in the target language. In this instance, when writing their English Language examinations, the G12 learners think and plan their written pieces of composition in their mother tongue which results in these lexical errors. They transfer the meaning from their mother tongue to English thereby hampering discourse comprehensibility.

\section{CONClusion}

The results of this study indicate that L1 lexical errors are committed by Grade Twelve pupils in their final English language paper 1 (composition) examinations every year as explained by the paper 1 Examiners who were interviewed at the marking centre. The literature review showed that many studies on L1 interference have been conducted in different areas.

Arising from the findings and the discussion thereof, it is the case that there is prevalence of the existence of L1 lexical errors in the scripts which were examined for the study. It is also the case that these errors hamper discourse comprehensibility resulting in low scores by learners. These findings have given a detailed description of the results of this research. In relation to the purpose of the current study, the findings seemed to suggest that most of L1 lexical errors committed by Grade Twelve learners are as a result of the writers thinking and planning their written pieces of composition in their mother tongue. The errors that were identified from the scripts gave evidence to this assertion. It indicated that L1 plays a considerable role in causing learners to make errors when they write their pieces of composition as they translate words or phrases directly from their L1 into L2. This tended to hamper discourse comprehensibility, resulting in low scores by the Grade Twelve learners.

The major implication of the findings seems to be that the learners have not sufficiently mastered the use of these items for enhancement of discourse comprehensibility. Much as the findings appear to be basic, they are still a challenge among the Grade Twelve learners as evidenced in their written examination scripts.

\section{RECOMMENDATIONS}

\subsection{Recommendation at Policy Level}

(i) Teacher trainers should redesign the English teachers' training curriculum to embed the influence of L1 interference of L2 learning.

(ii) Teacher trainers should strengthen both English content and English teaching methodology by making applied linguistics one of the core courses in the syllabus. 
(iii) The Ministry of Education should run remedial teaching as one of the capacity building initiatives for teachers of English.

(iv)The extensive reading programme should be enhanced in schools by allocating ample time to both in and outside classroom activities.

\subsection{Recommendations for Further Research}

(i) Similar studies should be conducted on first language interference errors at the levels of phonology, morphology and pragmatics.

(ii) Other studies should be conducted on first language interference errors in the written pieces in other essay written subjects such as History, Religious Education, Geography and Biology.

\section{REFERENCES}

[1] Abdallah (2011). Damascus University Journal, vol. 27, Number (1+2).

[2] Aito, E. (2005). James Cohen, Kara T. McAlister, K.Rolstad\& Je. MacSwan (Eds.), ISB4: Proceedings of the $4^{\text {th }}$ International Symposium on Bilingualism, 18-38. Somerville, MA: Cascadilla Press.

[3] Arab World English Journal V5 Number 4, 2014

[4] Bennui, P. (2008). Malaysian Journal of ELT Research, Vol.4 pp72 - 102

[5] Brown, D.H. (1980). Principles of Language Learning and Teaching. New Jersey: Prentice-Hall Inc.

[6] Corder, S.P. (1967).The Significance of Learners' errors. International Review of Applied Linguistics, 4, 161-170.

[7] Corder, S.P. (1974).Error Analysis. London: Longman.

[8] Corder, S.P. (1981).Error Analysis and Interlanguage. Oxford: Oxford University Press.

[9] Damascus University Journal, vol. 27, Number (1+2), 2011

[10] Duly, H., Burt, M., \&Krashen, S. (1982).Language Two. New York: Oxford University Press.

[11] Erdogan, V. (2009).Contribution of Error Analysis to Foreign Language Teaching. Journal of the Faculty of Education. Vol. 1.

[12] Fauziati, E. (2014). Ahmad Dahlan Journal of English Studies, Vol. 1, Issue 1-2.

[13] Fries, C.C. (1945).Teaching and Learning English as a Foreign Language. Ann Arbor: University of Michigan Press.

[14] Gass, S.M. and Selinker, L. (Eds.).(1994). Language Transfer in Language Learning. Amsterdam: John Benjamin.

[15] Hamjah,(2012).Error Analysis in Mother Tongue (Bima Language) Interference in Writing Skill.MA Thesis, Muhammadiyah University of Surakarta.

[16] Hasyim, S. (2002).Error Analysis in the Teaching of English. Vol. 4, No. 1, 42-52. Jurusan FakultasSastra, Universitas Kristen Petra.

[17] Hyland, K. (2016). Methods and methodologies in second language writing

[18] Research. Elsevier. journal homepage: www.elsevier.com/locate/system

[19] Jackson K.L. (1981).The Verification and Comparison of Contrastive Analysis. Work Papers In Linguistics. Hawaii, 3(4): 201-9.

[20] James, C. (1998). Errors in Language Learning and Use: Exploring Error Analysis. Harlow,, Essex: Addison Wesley Longman Limited.

[21] Kombo and Tromp (2009) Proposal and Thesis Writing. Nairobi Paulines Publications Africa.

[22] Lasaten, R.C.S. (2014). Analysis of Errors in the English Writing of Teacher Education Students: International Refereed Research Journal. Vol. Issue.

[23] Lerner, J. (2000). Learning Disabilities. USA: Houghton Mifflin Company.

[24] Locke, L.F, W.W.Spirduso, \&S.J. Silverman. (1987). Proposals that work: A Guide for Planning Dissertations and Grant Proposals. Newbury Park: CA Sage.

[25] Lott D. (1983).Analysing and Counteracting Interference Errors, ELT Journal Vol. 3713

[26] Michealides, N.N. (1990). Error Analysis. English Teaching Forum Vol. XXXVIII/4:28:30.

[27] MoongaIreen, (2012). An Analysis of Written English Errors Made by Grade 11 Pupils in a Multilingual Context: A Case of Selected Schools in Kabwe and Monze Districts of Zambia. M.Ed Thesis, UNZA. 
[28] Mukonde, E. (2009). A Pragmatic Analysis of Requests in Bemba. MA. Dissertation, University of Zambia.

[29] Nakuna, C.A. (1998). A New Theoretical Account of Fossilisation: Implications for L2 Attrition. International Review of Applied Linguistics in Language Teaching.

[30] Nesreen (2014 :). Arab World English Journal V5 Number 4.

[31] Noemi Soares Silva ISE (Instituto Superior Educacao ) dissertation

[32] Polonsky and Waller (2011) Designing and Managing a Research Project. London: SAGE Publications.

[33] Punch K.F. (2009).Introduction to Research Methods in Education. London: SAGE Publications.

[34] Qadi - AL. Nasser, S. (2009).A Sociolinguistic Composition of Euphemisms in English and Arabia: Taiban University, AL-Munawarah, Saudi Arabia.

[35] Revista De Lenguas Modernas, Number 14, 2011.

[36] Richard, N. (2015) http//www.bing.com) accessed on $18^{\text {th }}$ May, 2016.

[37] Richards.J. (1976).The Role of Teaching Vocabulary, TESOL Quarterly

[38] Richards, J.C., Platt, and H., Plott, J.(1996). Dictionary of Language Teaching and Applied Linguistics. London: Longman.

[39] Savignon, S.J. (1991). Communicative Language Teaching: State of the Art. TESOL Quarterly, Vol.25, No. 2, University of Illinois at Urbadana-Champaign.

[40] Silva S.N. (2008).Instituto Superior Educacao, dissertation.

[41] Silva, T. (1993).Writing in two languages: Differences in ESL and L1 writing. Manuscript submitted for publication.

[42] Sridhar, N.S. (1980). “Contrastive Analysis, Error Analysis, and Interlanguage: Three Phases of One Goal.” In Kenneth Croft (Ed.) 1980: 91-119.

[43] Stern H.H. (1983). Fundamental Concepts of Language Teaching. Oxford: Oxford University Press.

[44] Subramaniam, K. (2009). Error Analysis of the Written English Essays of Secondary School Students in Malaysia: A Case Study. School of Language Studies and Linguistics Faculty of Social Sciences and Humanities. Universiti Kebangsaan Malaysia, 43600 UKM Bangi Selangor Malaysia.

[45] Swann, J. (1992). Girls, Boys and Language. U.S.A: Blackwell Publishers.

[46] Tarone,E.E. (1987). Methodologies For Studying Variability in Second Language Acquisition in R. Ellis(Ed). Second Language Acquisition in context (pp. 35-46).London: Prentice-Hall.

[47] The Asian Conference on Language Learning 2013

[48] Thornbury,S. (1999).How to Teach Grammar. Essex: Longman.

[49] Walters, D.B. (1979). The Legal Recognition and Protection of Language Pluralism in Actica Juridica, III: 305-326. Cape Town: Juta.

[50] Wilkins, D.A. (1972). Linguistics in Language Teaching. London: Edward Arnold.

[51] Dechert, H.W. 1983, 'How a story is done in a secondlanguage' in Strategies in Interlanguage Communication, eds. C. Faerch and G. Kasper, Longman, London.

\section{AUTHOR'S BIOGRAPHY}

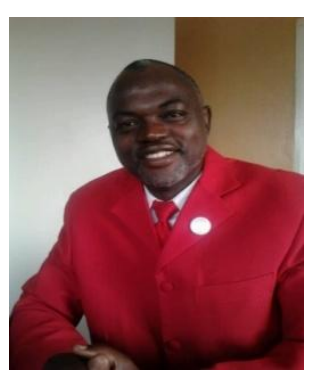

Mr. Lazarous Fred Sinkala, Secondary School Teacher of English Language and. M.A. Linguistic Science candidate, University of Zambia. Department of Social Sciences. Mpelembe Secondary School, Zambia, Chief Examiner, School Certificate English Language and Chief Marker, Junior Certificate English Language, Author and Publisher.

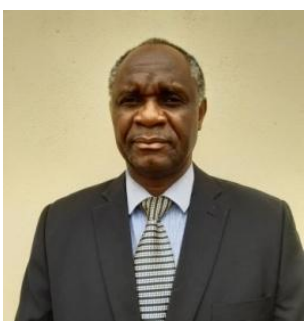

Dr. Gift Kaira, lecturer, Researcher and Acting Dean, School of Education. Department of Education Institution name: Mulungushi University, Zambia. Applied Linguistics, Sociolinguistics and Foreign Languages 


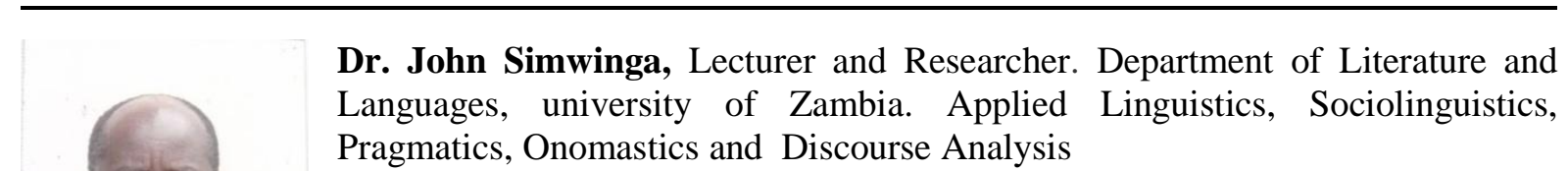

Citation: Lazarous Fred Sinkala, et.al. " "His Car Refused to Cry": An Analysis of L1 Interference Lexical Errors in Zambian Grade 12 Esllearners' Written Discourse " International Journal of Humanities Social Sciences and Education (IJHSSE), vol 7, no. 4, 2020, pp. 73-94. doi: http://dx.doi.org/10.20431/23490381.0704009.

Copyright: () 2020 Authors. This is an open-access article distributed under the terms of the Creative Commons Attribution License, which permits unrestricted use, distribution, and reproduction in any medium, provided the original author and source are credited. 